\title{
Biogas recovery from fresh landfill leachates by using a coupled air stripping-up follow anaerobic sludge blanket (UASB) process
}

\author{
Abd-essamad MOUJANNI ${ }^{\dagger}$, Imane QARRAEY, Aaziz OUATMANE \\ Agroressource, Bioenergy and Environment Team, Sciences and Technology Faculty, Sultane Moulay Slimane University, Box 523 Beni Mellal, Morocco
}

\section{ABSTRACT}

The present study focuses on fresh leachates treatment using anaerobic digestion. To overcome the unsuitable raw characteristics, appropriate pretreatment conditions were identified based on Batch tests. A subsequently optimized pretreatment-anaerobic two stages UASB coupled treatment was studied. The performance of the overall coupled treatment was assessed by monitoring volatile fatty acids (VFA), COD and ammonium removal, and biogas performance. Results showed that combining acidity correction to short aeration gives a synergetic effect and allowed appropriate anaerobic start-up conditions. Under continuous aerobic pretreatment-UASB digestion, significant removal of $\mathrm{NH}^{+}{ }_{4}(75.87 \%)$, COD $(19.14 \%)$, and VFA $(20.3 \%)$ were achieved during the aeration step resulting in the total abatement of $88.66 \%, 83.6 \%$ and $70.39 \%$ for $\mathrm{NH}^{+}{ }_{4}$, COD, and $\mathrm{VFA}$, respectively. The process allowed good biogas performance up to $2,470 \mathrm{~mL}$ biogas/ $\mathrm{L}$ and $123 \mathrm{~mL} \mathrm{CH} / \mathrm{gCOD}$ removed, with gradual improvement from the first to the second UASB reactor. Inlet COD and VFA feeding rate seemed to be the main key parameters with $45.37 \mathrm{~g}$ COD/L.d and $18.43 \mathrm{~g} \mathrm{VFA} / \mathrm{L} . \mathrm{d}$ as a critical threshold. Therefore, the anaerobic digestion of high COD leachates is highly feasible and the aerobic-anaerobic coupled treatment is a promising technical scenario that deserves further studies.

Keywords: Aeration pretreatment, Batch test, Methane, Municipal fresh wastes leachates, UASB

\section{Introduction}

Leachate is currently the most technical drawback and the challenge of wastes landfilling worldwide. The commonly used technologies present serious technical problems due to the harmful character of landfill leachates and their high chemical oxygen demand, low biodegradability, high ammonium ions content and acidity, as well as too high salt contents [1-4].

Coupled and multistage treatment is often needed due to a lack of efficient single treatment that could meet legal discharge requirements [1, 5-8]. Coupled processes based on various combinations, particularly nitrification-denitrification, ultrafiltration, nanofiltration, and reverse osmosis are the major full scale used technologies [9-12].

Due to economic and technical problems, much more attention is being recently accorded to biological treatments [13-17], particularly the anaerobic treatments that could allow simultaneously high treatment performance and energy recovery $[10,18,19]$. Although the post-treatment process remained always unavoidable to eliminate salts and inorganic compounds, the anaerobic based technologies are currently very attractive, particularly as pretreatment and additional landfill on-site energy recovery option the same time [20]. Recent research findings showed that microbial electrochemical system and the supplementation of granular carbon are a promising methods for enhancing anaerobic digestion (AD) performance and biogas production [21-23].

Anaerobic biodegradation of leachate is similar to the anaerobic processes occurring inside municipal waste landfills and many works showed that landfill leachates are nutrient-rich effluents with methane production potential close to that of many other easy biodegradable effluents such as food wastes leachates and wastewater sewage sludge [24-28]. The methane yield depends on wastes characteristic and digestion conditions, in general, the yield of fresh leachate, food waste and raw sludge vary usually from 0.28 to $0.38,0.082$ to 0.521 and 0.09 to $0.43 \mathrm{~L} \mathrm{CH}_{4} / \mathrm{g}$ VS respectively [29, 30]. Young leachates are commonly highly biodegradable compounds and were reported to be more suitable for anaerobic digestion than the old one [31, 32]. By using either anaerobic membrane reactors, completely stirred tank reactors (CSTR) and up-flow anaerobic sludge blanket reactor (UASB),
This is an Open Access article distributed under the terms of the Creative Commons Attribution Non-Commercial License (http://creativecommons.org/licenses/by-nc/3.0/) which permits unrestricted non-commercial use, distribution, and reproduction in any medium, provided the original work is properly cited.

Copyright (C) 2022 Korean Society of Environmental Engineers
Received August 14, 2020 Accepted December 10, 2020

${ }^{\dagger}$ Corresponding author

E-mail: moujanni01@gmail.com

Tel: +212649182764 Fax: +212523485201

ORCID: 0000-0002-6483-7470 
it was reported that anaerobic treatment is the promising way that could reduce significantly the dissolved organic content of raw leachate and allows both technical and economic advantage regarding the overall treatment cost [3, 33-35]. According to many anaerobic UASB fresh leachates treatment, COD removal rate up to $86.3 \%$ was always recorded and biogas production rate varies from 0.27 to $0.35 \mathrm{~L} / \mathrm{g}$ COD removed, with very high $\mathrm{CH}_{4}$ content [36].

Even though anaerobic UASB reactors are still of limited use at full scale, the main advantages of UASB technology are associated to its suitability to achieve good performance within large organic feeding range that could cover most landfill leachate's characteristics as confirmed through many lab-scale studies [37, 38]. The simplicity of UASB technology and its convenience to achieve good energy performance under different climatic conditions, as confirmed by most full-scale sewage sludge UASB reactors and wastewaters treatment plants [39-41] make UASB technology very attractive.

With the new perspective of using the anaerobic process for both treatments and energy recovery purposes, the overall composition of landfill leachate is however of great concern. Many leachates constituents are potential inhibitors of anaerobic bacteria and this limit the feasibility and convenience of anaerobic treatment. Volatile fatty acids, ammonia and acidity are usually present at high concentrations that could compromise anaerobic leachate treatment as reported in the literature [42-44]. For young leachates such as those of most developing countries, anaerobic treatment could be a challenging alternative as the anaerobic process may need various pretreatments. Up today, few works have been consecrated to fresh (before dumping) waste leachates recovery and no work was done regarding anaerobic recovery of Moroccan municipal solid wastes leachates. In previous work, we confirmed that codigestion of similar fresh leachates with wastewater is feasible and could be a potential alternative for an eventual centralized treatment at biogas recovery-based wastewater plants in Morocco [45].

For most Moroccans cities, huge quantities of fresh leachates are daily produced during waste collection and transport, particularly during the warm season. Those leachates are usually mixed with landfill leachates, and treated by their recycling or solar evaporation. Fresh wastes leachates are however COD-rich effluents and are easily biodegradable, with interesting biogas recovery potential even though their acidity makes them incompatible with anaerobic digestion. Therefore, landfill on-site energy recovery is an attractive technical scenario for both treatment purpose and optimization of existing landfill biogas recovery installations.

The present research focuses on this perspective and evaluates the suitability of Moroccans fresh municipal wastes leachates to anaerobic digestion using UASB based treatment. Optimal starting digestion conditions were assessed through preliminary aeration based pretreatment under Batch conditions. Thereafter, the performance of an optimized coupled aeration-UASB process was investigated and assessed based on COD, ammonium, and VFA removal rate and biogas and methane specific yields monitoring.

\section{Materials and Methods}

\subsection{Leachates Sampling and Origin}

The used leachates in this study were collected before waste dumping from separate waste collector vehicles at the entrance of the Béni Mellal sanitary landfill (Morocco). The landfill site covers approximately 200,000 $\mathrm{m}^{2}$ and receives about 160 tons of municipal solid wastes per day with an amount of daily fresh leachates production estimated to $20-60 \mathrm{~m}^{3}$, depending on the season. After bulk mixing and two days ambient temperature decantation, the decanted mineral sludge was discarded and the supernatant was sieved to $1 \mathrm{~mm}$ to remove suspended material and then stored at $4^{\circ} \mathrm{C}$ until use. The main characteristic of the prepared fresh leachates is reported in Table 1. The inoculum was collected from the existing anaerobic digestion wastewaters plant of Khouribga city (Morocco). The fresh leachate composition showed a relatively high level of COD $\left(53.49 \pm 1.81 \mathrm{~g} \mathrm{O}_{2} / \mathrm{L}\right)$ ammonium $(852.17 \pm 25 \mathrm{mg} / \mathrm{L})$ and acidic $\mathrm{pH}(4.85 \pm 0.52)$. Likewise, the inoculum was characterized by a neutral $\mathrm{pH}$ (7.5) and total volatile solid content of $0.179 \%$ (dry basis). It was kept at lab ambient temperature with manual intermittent stirring and was used as-is for all $\mathrm{AD}$ tests.

Table 1. Characteristics of Fresh Leachate from Béni Mellal City Sanitary Landfill

\begin{tabular}{lcc}
\hline Parameters & Average value & Standard deviation \\
\hline Temperature & 32.000 & 4.00 \\
$\mathrm{pH}$ & 4.850 & 0.52 \\
Conductivity (mS/cm) & 25.690 & 1.32 \\
$\mathrm{VS}(\mathrm{g} / \mathrm{L})$ & 38.000 & 0.80 \\
$\mathrm{COD}\left(\mathrm{gO}_{2} / \mathrm{L}\right)$ & 53.490 & 1.81 \\
$\mathrm{NTK}(\mathrm{g} / \mathrm{L})$ & 2.960 & 85.00 \\
$\mathrm{VFA}(\mathrm{g}(\mathrm{acetic}$ acid)/L) & 23.020 & 0.75 \\
$\mathrm{Ammonium}(\mathrm{mg} / \mathrm{L})$ & 852.170 & 25.00 \\
$\mathrm{Cd}(\mathrm{mg} / \mathrm{L})$ & 0.019 & 0.004 \\
$\mathrm{~Pb}(\mathrm{mg} / \mathrm{L})$ & 0.330 & 0.14 \\
$\mathrm{Cu}(\mathrm{mg} / \mathrm{L})$ & 1.560 & 0.01 \\
$\mathrm{Zn}(\mathrm{mg} / \mathrm{L})$ & 6.500 & 1.45 \\
$\mathrm{Fe}(\mathrm{mg} / \mathrm{L})$ & 4.510 & 1.50 \\
\hline
\end{tabular}

\subsection{Aerobic Pretreatment}

To determine appropriate pretreatments conditions that could allow anaerobic digestion, to be consequently applied as a pretreatment before UASB treatment, a preliminary experiment was carried out using Batch tests. Pretreatments were based on both the fundamental main starting conditions of $\mathrm{AD}$ (organic loading rate, ammonium content and Acidity) commonly reported in literature [46] and according to recent pretreatment investigations finding that recommended air striping and acidity correction among other parameters [47]. The objective was to identify appropriate start-up conditions while using non-diluted leachates. Applied pretreatments were consequently limited to acidity correction, $48 \mathrm{~h}$ air stripping as 
Table 2. Batch Pretreatments Conditions and Gompertz Model Kinetic Obtained for Different Pretreatments Tests under Mesophilic Temperature Conditions

\begin{tabular}{|c|c|c|c|c|}
\hline Reactor code & Anaerobic sludge inoculation* & pH correction to 7.5 & $0.1 \mathrm{~N})$ & Air stripping (48 h) \\
\hline $\mathrm{R}_{0}$ (Blanc Reactor) & + & - & & - \\
\hline $\mathrm{R}_{\mathrm{pH}}$ & + & - & & + \\
\hline $\mathrm{R}_{\mathrm{O} 2}$ & + & + & & - \\
\hline $\mathrm{R}_{\mathrm{pH}+\mathrm{O} 2}$ & + & + & & + \\
\hline \multicolumn{5}{|c|}{ Kinetic parameters associated with the Gompertz model } \\
\hline & $\mathbf{r}^{2}$ & $A(\mathrm{~mL} / \mathrm{gVS})$ & $\mu(\mathrm{mL} / \mathrm{gVS} . \mathrm{d})$ & $\lambda(d)$ \\
\hline $\mathrm{R}_{0}$ (Blanc Reactor) & ND & ND & ND & ND \\
\hline $\mathrm{R}_{\mathrm{O} 2}$ & 0.9978 & 29.21 & 1.08 & 24.59 \\
\hline $\mathrm{R}_{\mathrm{pH}}$ & 0.9976 & 11.65 & 0.69 & 33.73 \\
\hline $\mathrm{R}_{\mathrm{pH}+\mathrm{O} 2}$ & 0.9998 & 108.77 & 3.99 & 19.45 \\
\hline
\end{tabular}

*inoculum from anaerobic wastewaters Plan of Khouribga city, Morocco

+ : Yes , -: No, ND: not determined

recommended by other auteurs [47-49], and their combination as illustrated in Table 2. A test containing only inoculum and distilled water was conducted under the same conditions and was used as control pretreatment.

The used Batch reactors were 1.5 L total volume of and $1.3 \mathrm{~L}$ working volume and were equipped with a gas-tight bag for biogas accumulation. After the pretreatment step, each reactor was inoculated by $100 \mathrm{~mL}$ of inoculum and bubbled by nitrogen $\mathrm{N}_{2}$ for $5 \mathrm{mn}$ and then maintained at mesophilic temperature $\left(37 \pm 2^{\circ} \mathrm{C}\right)$ using a water lab bath. The produced biogas was measured every 3 days interval by the water displacement method. For a better description of biogas production kinetic, cumulative biogas data were fitted to Modified Gompertz equation [50-52] using Eq. (l)

$$
P=A \exp \left\{-\exp \left[\left(\mu \cdot \frac{e}{A}\right)(\lambda-t)+1\right]\right\}
$$

Where, $P$ is the cumulative biogas, $A$ is the maximum biogas production potential ( $\mathrm{mL}$ biogas. $\mathrm{g}^{-1} \mathrm{VS}$ removed); $\mu$ is the specific rate constant ( $\mathrm{mL}$ biogas. $\mathrm{g}^{-1}$ VS removed. $\mathrm{d}^{-1}$ ); and $\lambda$ is the lag time (d). The three parameters (A, $\mu$ and $\lambda$ ) were estimated by curve fitting using the MATLAB program.

\subsection{UASB Digestion Based Treatment}

UASB treatment process was based on Batch pretreatment results and consisted of acidity correction-air stripping pretreatment that was coupled to two steps UASB reactors (UASBR1 and UASBR2) in a continuous coupled process as described in Fig. 1. UASB was chosen due to its convenience to support high organic loading and the possibility of leachates treatment without additional dilution pretreatment need.

Pretreatment step was done using $10 \mathrm{~L}$ capacity Pilote Aerobic Reactor (model SGI) that allows continuous feeding of the UASB step by pretreated leachates (continuous control of $\mathrm{pH}$ correction, air stripping flow and temperature). UASB treatment step was composed of two circulars PVC reactors having $78 \mathrm{~cm}$ height and $7 \mathrm{~cm}$ diameter offering a total volume of $3 \mathrm{~L}$ each one, with conic

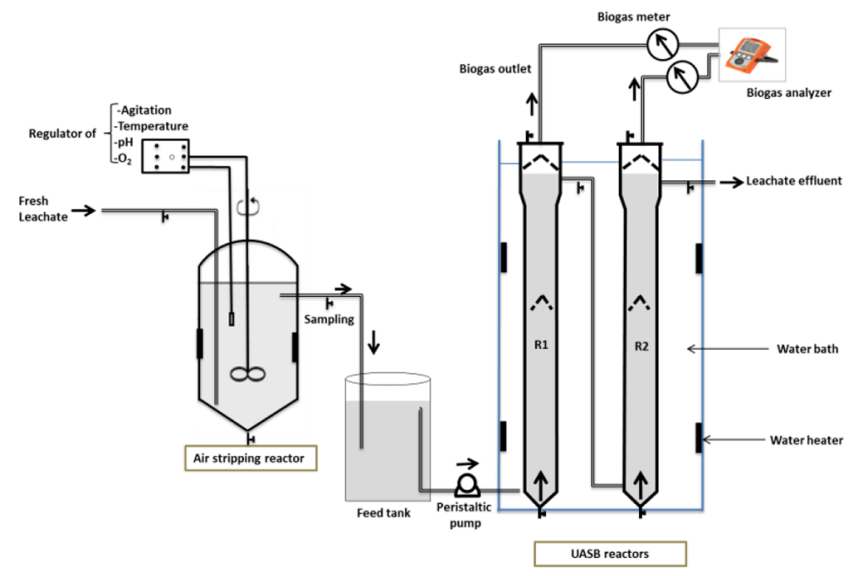

Fig. 1. Coupled air stripping and UASB continuous process setup under mesophic temperature conditions.

separators to improve liquid/biogas separation and prevent sludge washing-out. The two UASB reactors were initially inoculated with $100 \mathrm{~mL}$ of inoculum and were first operated at Batch mode for one month start-up period and then at continuous mode at a hydraulic retention time (HRT) of $24 \mathrm{~h}$ for additional $20 \mathrm{~d}$ until anaerobic steady-state conditions achievement. Therefore, HRT was increased to $36 \mathrm{~h}$ and then decreased to $24 \mathrm{~h}$ and $12 \mathrm{~h}$ while keeping digestion for one month period for each HRT. Organic loadings were kept within Batch tests range and the resulting up-flow velocity was at low values discarding biomass washing risk (Table 3). UASB digestion step was operated at mesophilic conditions $37 \pm 2^{\circ} \mathrm{C}$ using water bath dispositive. During the overall $\mathrm{AD}$ period, biogas was determined by water displacement method and leachates were sampled by syringe twice a week at the following steps: raw fresh leachates, pretreated leachates, UASB-R1 treated leachates and UASB-R2 treated leachates (outlet effluents) as shown in Fig. 1. The performance of the whole anaerobic-aerobic process was assessed by monitoring COD, ammonium and VFA removals and through volumetric biogas yield and composition. 
Table 3. Principal Geometrical Characteristics and Operational Parameters of UASB Reactors as a Function of Different HRT

\begin{tabular}{lccccc}
\hline \multirow{2}{*}{ Times (d) } & HRT (h) & Flow rate (L/h) & Up flow velocity (m/h) & \multicolumn{2}{c}{ Average OLR (g COD/L.d) } \\
\hline $1-30$ & 36 & 0.0833 & 0.0139 & $27.28 \pm 1.30$ & UASB-R1 \\
$30-60$ & 24 & 0.1250 & 0.0208 & $45.37 \pm 1.12$ & $12.32 \pm 1.36$ \\
$60-90$ & 12 & 0.2500 & 0.0417 & $86.93 \pm 1.92$ & $49.20 \pm 1.89$ \\
\hline
\end{tabular}

\subsection{Analytical Methods}

All the analytical analysis were done according to standard methods $[53,54]$. Total nitrogen and ammonium concentration were determined by classical digestion and Kjeldahl distillation and titration. COD and VFA were measured using the titrimetric and titration methods respectively. Volatiles solid content was determined after samples overnight ignition at $550^{\circ} \mathrm{C}$, and heavy metals concentrations were determined on ash by Inductively Coupled Plasma Atomic Emission Spectroscopy (CP-AES CP Optima 8300DV). Volumetric determination of biogas was done using lab water displacement column that allowed biogas yield at normal atmospheric pressure (1atm). Biogas composition was done using portable Biogas Multitec ${ }^{\circledR} 540$ gas analyzer for $\mathrm{CH}_{4}$, $\mathrm{CO}_{2}, \mathrm{O}_{2}$ and $\mathrm{H}_{2} \mathrm{~S}$ free moisture determination. Biogas volumes were determined at lab temperature and converted to standard conditions $(273.15 \mathrm{~K}$ and $1 \mathrm{~atm})$ using the ideal gas law (PV = nRT).

\section{Results and Discussion}

\subsection{Leachates Composition and Characteristics}

During the warm season, biodegradation of household waste is generally fast and lead to the production of important volumes of fresh leachates during waste collection and transport in most Moroccan cities. To investigate the suitability of these effluents to anaerobic recovery, samples were analyzed and the main parameters are listed in Table 1. The studied leachates were characterized by very low $\mathrm{pH}$ (4.85) and high volatile fatty acids contents (23.02 $\pm 0.75 \mathrm{~g} / \mathrm{L})$. Concentrations of COD $(53.49 \pm 1.81 \mathrm{~g} / \mathrm{L})$ and total nitrogen and ammonium $(852.17 \pm 25 \mathrm{mg} / \mathrm{L})$ were also relatively high, compared to that of common landfill leachates [6] including Moroccans landfills leachates [55]. The ratio COD/NTK was also close to 17 and was within the optimal range (16 to 30) for bacteria growth [56]. Metallic ions, heavy metals and electrical conductivity showed values at non-limiting ranges. The overall composition was characteristic of leachates from biowaste being at advanced hydrolysis stage.

From a biological treatment point of view, it is clear that both COD content and ammonium and total nitrogen content were suitable for anaerobic recovery treatments [57] and may lead to important biogas recovery. However, the acidity character of these leachates was a major constraint to anaerobic treatment. Besides, the high biodegradability of these effluents and their high COD and VFA should generally be taken with precaution as this may lead to fast acids accumulation and subsequent inhibition of methanogenic archaea [57, 58].

\subsection{Aerobic Pretreatment}

Young and fresh leachates are commonly unsuitable to anaerobic digestion unless subjected to the dilution that needs important quantities of waters and produces at the same time huge volumes of effluents. To overcome this problem, while using non-diluted fresh leachates, a pretreatment test based on acidity correction and aerobic treatment was investigated. The obtained results are reported in Fig. 2. Control reactor containing the only $100 \mathrm{~mL}$ of inoculum has produced negligible biogas (data not shown) and this was obviously attributed to its low organic carbon content. Untreated leachates (Reactor R0) were also highly acid and this was unfavorable and inhibits totally the anaerobic digestion process.
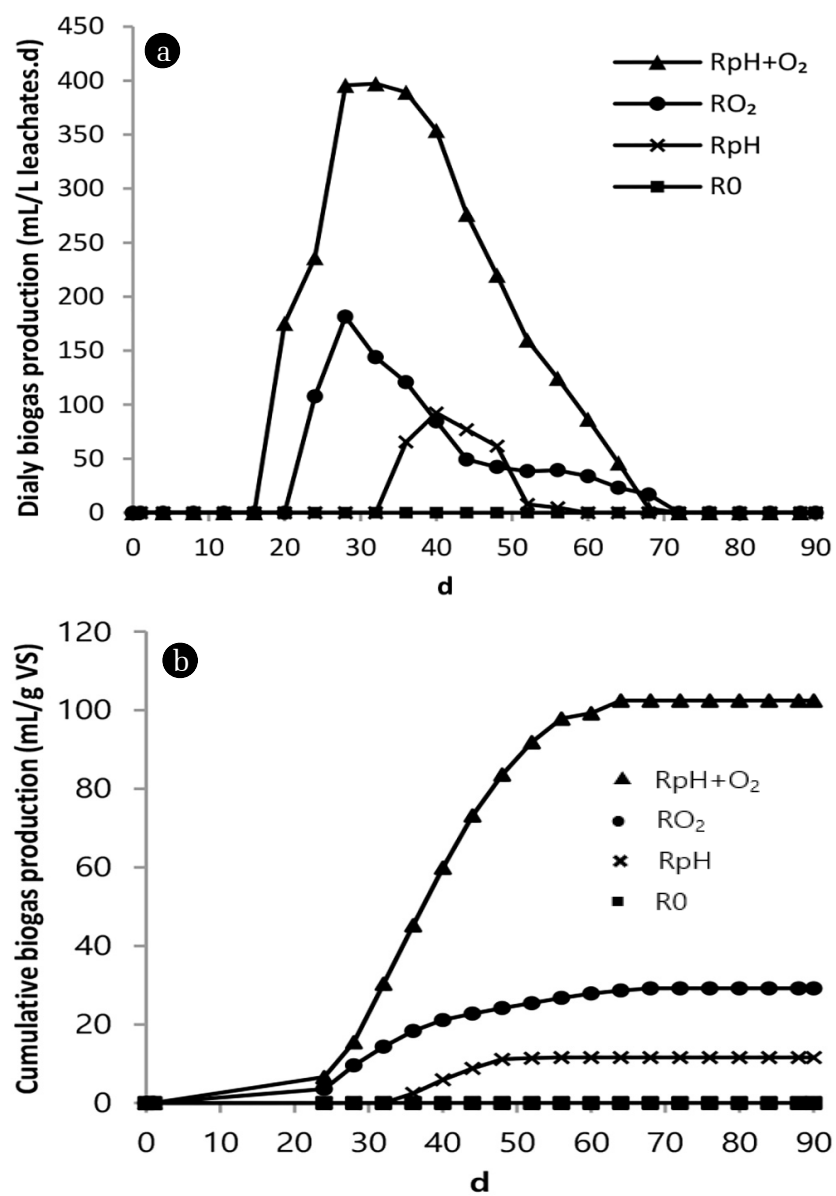

Fig. 2. Batch daily biogas production (a) and cumulative production simulated by the Modified Gompertz model (b) as a function of different pretreatment under mesophilic temperature conditions. 
On the opposite, $\mathrm{pH}$ correction and air stripping, pretreatments had shown a significant positive effect and allowed leachates to undergo anaerobic digestion. Without $\mathrm{pH}$ correction, it was noticed that entering the anaerobic process took longer with the shortest period of biogas production. On the contrary, acidity correction without aeration gives relatively high biogas yield and short acclimation period at the same time. The highest biogas yield was however achieved when leachates were submitted to the combination of the two pretreatments (Reactor $\mathrm{R}_{\mathrm{pH}+\mathrm{O} 2}$ ).

Plots of cumulative recorded biogas yields and potential according to the Gompertz model confirmed normal biogas production kinetic with highly significant correlation coefficient $\left(\mathrm{R}^{2}=0,999\right)$ between experimental and predicted data (Fig. 2 and Table 2). Data comparison showed an obvious synergetic effect in case of a combination of acidity correction and air stripping with the maximum biogas potential and maximum daily rate of $108 \mathrm{~mL} / \mathrm{g} \mathrm{VS}$ and $4 \mathrm{~mL} / \mathrm{g}$ VS.d, respectively. These results agree with various aerobic pretreatment studies for which air stripping induce positive effect due to either ammonia removal or acidity buffer improvement, particularly trough VFA biodegradation [49, 59, 60]. According to the recent work of [47], it seems that ammonium removal during air stripping may also improve the $\mathrm{C} / \mathrm{N}$ ratio and makes leachates highly biodegradable and suitable for anaerobic bacteria growth. Other authors showed that air stripping stimulates biological consumption of easy biodegradable compounds and contribute to COD and $\mathrm{BOD}$ removal which improves in turn $\mathrm{AD}$ and biogas production [61]. Interestingly, the present study showed that aeration had also a meaningful effect since biogas production was possible without acidity correction. A similar effect was reported by [59] for which intermittent aeration in hybrid bioreactor decreased significantly VFA and increased the $\mathrm{pH}$ of leachates to neutral values within 10 weeks, resulting in biogas production stimulation, without acidity correction. It seems that when the pretreatment is limited to aeration, biological acids consumption may be longer but could effectively enhance $\mathrm{pH}$ and improve in turn both biodegradation process and anaerobic start-up digestion. The aeration effect was at the same time strongly improved by prior acidity correction. Accordingly, considering the whole physico-chemical composition of the used leachates, it is more likely that the obtained synergetic effect could be associated to the involvement of various parameters including acidity improvement, VFA, COD and ammonium biodegradation, with reciprocal positive effects.

\subsection{UASB Based Treatment}

The batch study showed that acidity correction and 48h air stripping pretreatment makes anaerobic digestion of acids and COD-rich leachates feasible and improves considerably methane yield and production lag time. The suitability of this pretreatment to leachates recovery was tested through its application at the head of a two-reactor UASB continuous process. The performance of the proposed treatment was assessed taking into account both the anaerobic and aerobic steps and specific effects.

\subsubsection{VFA, COD and ammonium overall abatement performance} Results of VFA and COD monitoring and removal rates as a function of the treatment steps and applied HRT are reported in Fig. 3. The coupled aerobic-anaerobic process showed good overall organic carbon abatement performance with total removal rate in the range of 64 to $70.39 \%$ and 72.42 to $83.6 \%$ for VFA and COD, respectively. Treatment steps comparison showed that the contribution of the
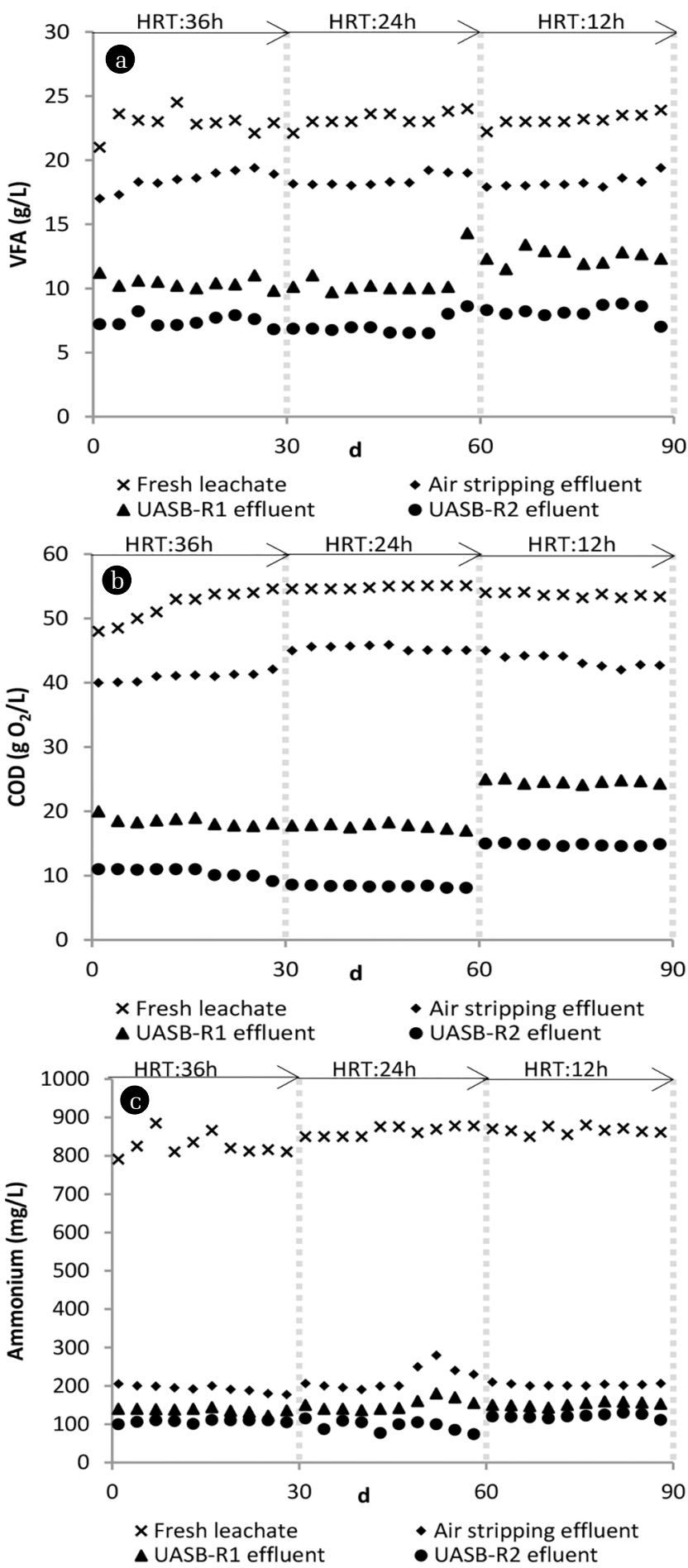

Fig. 3. VFA (a), COD (b) and Ammonium (c) evolution as a function of treatment step and HR under mesophilic temperature conditions. 
aerobic pretreatment to total abatement was significant. Leachates inlet concentrations were reduced at the aerobic step from an average value of $53.49 \pm 1.81 \mathrm{~g} \mathrm{COD} / \mathrm{L}$ and $23.02 \pm 0.75 \mathrm{~g} \mathrm{VFA} / \mathrm{L}$ to 43.25 $\pm 1.97 \mathrm{~g} \mathrm{COD} / \mathrm{L}$ and $18.33 \pm 0.61 \mathrm{~g} \mathrm{VFA} / \mathrm{L}$, respectively. Based on the whole monitoring period (90 d), achieved removal rates at pretreatment step were close to $20.3 \% \pm 2.62$ for VFA and $19.14 \%$ \pm 2.37 for COD.

Ammonium performance removal supported COD and VFA results and showed high and stable abatement performance with removal rate that was in the range of 86 to $88.66 \%$ (Fig. 3). Contrary to COD and VFA, most ammonium removals were achieved during the aeration pretreatment step resulting in concentration reduction from $852.17 \pm 25$ to $204.93 \pm 20 \mathrm{mg} / \mathrm{L}$ and removal rate of 75.95 $\pm 2.19 \%$. These results agree with Batch tests findings and conclusions and confirmed that aerobic pretreatment had a positive effect on organic acids metabolism and COD and ammonium biological consumption. Although few works had been consecrated to aerobic pretreatment effect regarding leachates anaerobic recovery, our results agree with most recent available researches as cited above at Batch paragraph. The strong achieved ammonium removal rate may be attributed to intense nitrification and microbial assimilation of ammonium. Similarly, COD and VFA loss at aeration step suggest that a significant proportion of dissolved organic carbon consisted of easy biodegradable compounds. Similar results were reported by [49, 51] for which the application of 2 to 5 days aerobic pretreatment to food waste enhanced both VFA and COD loss and this improved the biochemical methane potential. They stated that aerobic pretreatment stimulates hydrolysis and anticipate thereafter biogas production via shortening the methanogenesis phase. For the present study, it seems that anaerobic pretreatment improved the acidity buffer of leachates while it contributes to significant organic load abatement at the same time.

Monitoring data showed that the removal process continues at higher rates during the anaerobic UASB step, resulting in significant overall removals performances. Depending on HRT and UASB stage, recorded removal rates were in the range of $42.9 \%$ \pm 3.2 to $49.8 \% \pm 2.3,53.4 \% \pm 0.013$ to $67.5 \% \pm 2.3$ and $9.5 \%$ \pm 0.82 to $14.3 \% \pm 2$ for VFA, COD and ammonium, respectively. The highest removal values were achieved at $24 \mathrm{~h}$ and $36 \mathrm{~h}$ HRT followed by $12 \mathrm{~h} \mathrm{HRT}$. Reactors inlet and outlet concentrations comparison showed that using two UASB stages was advantageous in a sense that up to $20.89 \%$ and $19.91 \%$ of COD and VFA was removed at the second reactor. Based on total removal, the recorded values were highly significant and were within the common removal range that is usually reported in the literature [57].

\subsubsection{Biogas recovery and performance}

Results of Biogas yield and composition are reported in Fig. 4. The produced biogas had a high and relatively stable methane rate that varied in a narrow range (68 to 79\%) irrespective of HRT and UASB stage. Volumetric biogas yields results showed that the highest yields were recorded at $36 \mathrm{~h}$ and $24 \mathrm{~h} \mathrm{HRT}$ and that decreasing HRT to $12 \mathrm{~h}$ had a negative effect. In terms of methane yield, the recorded volumes corresponded to $1.84 \pm 0.18,1.87$ \pm 0.1 and $0.22 \pm 0.006 \mathrm{~L} \mathrm{CH}_{4} / \mathrm{L}$ of treated leachates and 0.123 $\pm 0.004,0.112 \pm 0.003$ and $0.015 \pm 0.001 \mathrm{~L} \mathrm{CH}_{4} / \mathrm{gCOD}$ removed for $36 \mathrm{~h}, 24 \mathrm{~h}$ and $12 \mathrm{~h} \mathrm{HRT}$, respectively. Under favorable conditions which were achieved with $24 \mathrm{~h}$ and $36 \mathrm{~h}$ HRT, total methane production represents 32 to $35 \%$ of the theoretical value of $0.35 \mathrm{~L}$ $\mathrm{CH}_{4} / \mathrm{g}$ COD removed [63]. Compared to similar UASB fresh leachates digestion [57], the recorded biogas had similar to high methane rate but relatively low methane volumetric yield. Likewise, the OLR used is very low (3-16 $\mathrm{kgCOD} / \mathrm{m}^{3}$.d) compared to our study and the biogas yields obtained vary between 0.2 to $0.4 \mathrm{~m}^{3} / \mathrm{kg}$ COD removed. The pretreatment had a positive effect and makes anaerobic digestion significant but it seems that the digestion process was still close to overloading condition, resulting in moderate methane yield.

For a better understanding of the anaerobic digestion process, methane yields to removed COD ratios were correlated to the main inlet parameters (COD, VFA and ammonium). No significant correlation was found (data not shown) for ammonium and this was attributed to the fact that inlet concentrations varied between 118-412 mg/L.d that is totally not limiting range [64]. However, it was observed that the performance of the UASB digestion step was negatively correlated with inlet COD and VFA feeding rates (Fig. 5). Increasing inlet COD feeding load over 45.37 g/L.d and VFA over $18.43 \mathrm{~g} \mathrm{VFA/L.d,} \mathrm{that} \mathrm{accompanied} \mathrm{HRT} \mathrm{decreases} \mathrm{to}$
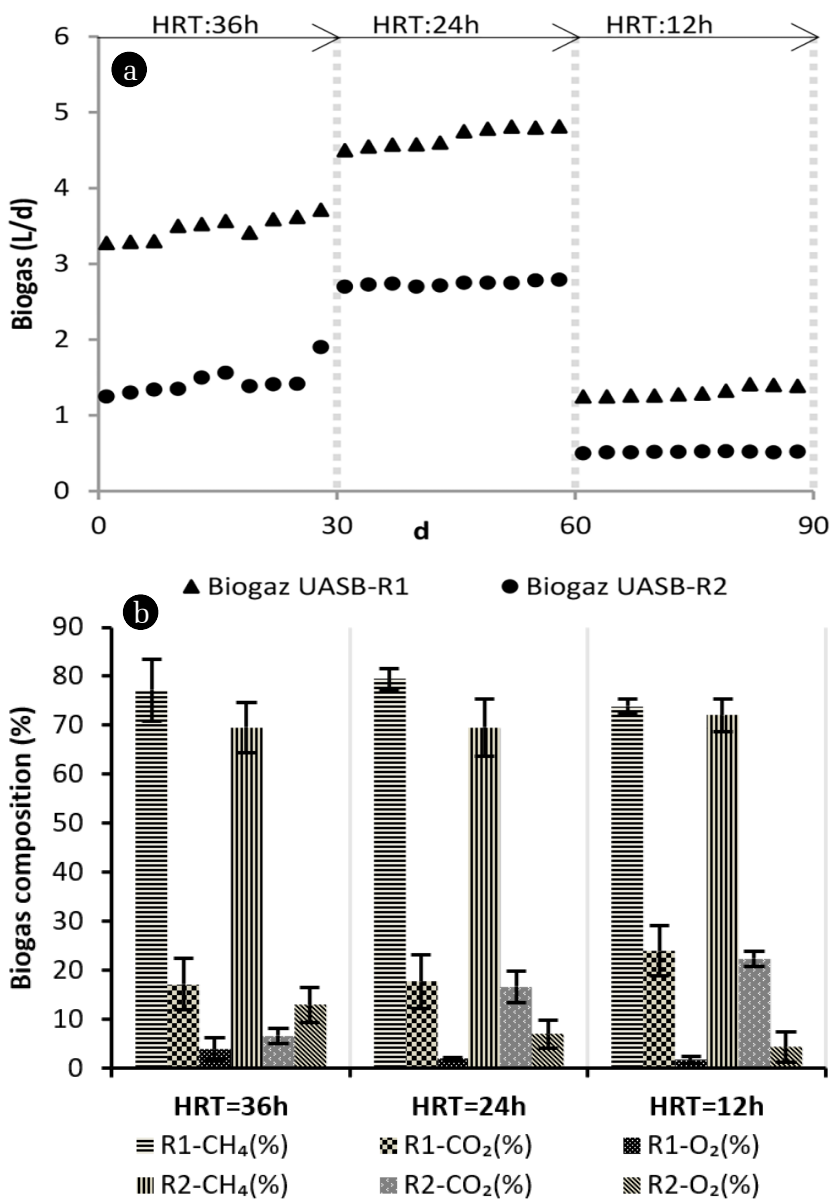

Fig. 4. Daily biogas production (a) and Average biogas composition (b) as function of HRT and UASB steps under mesophilic temperature conditions. 

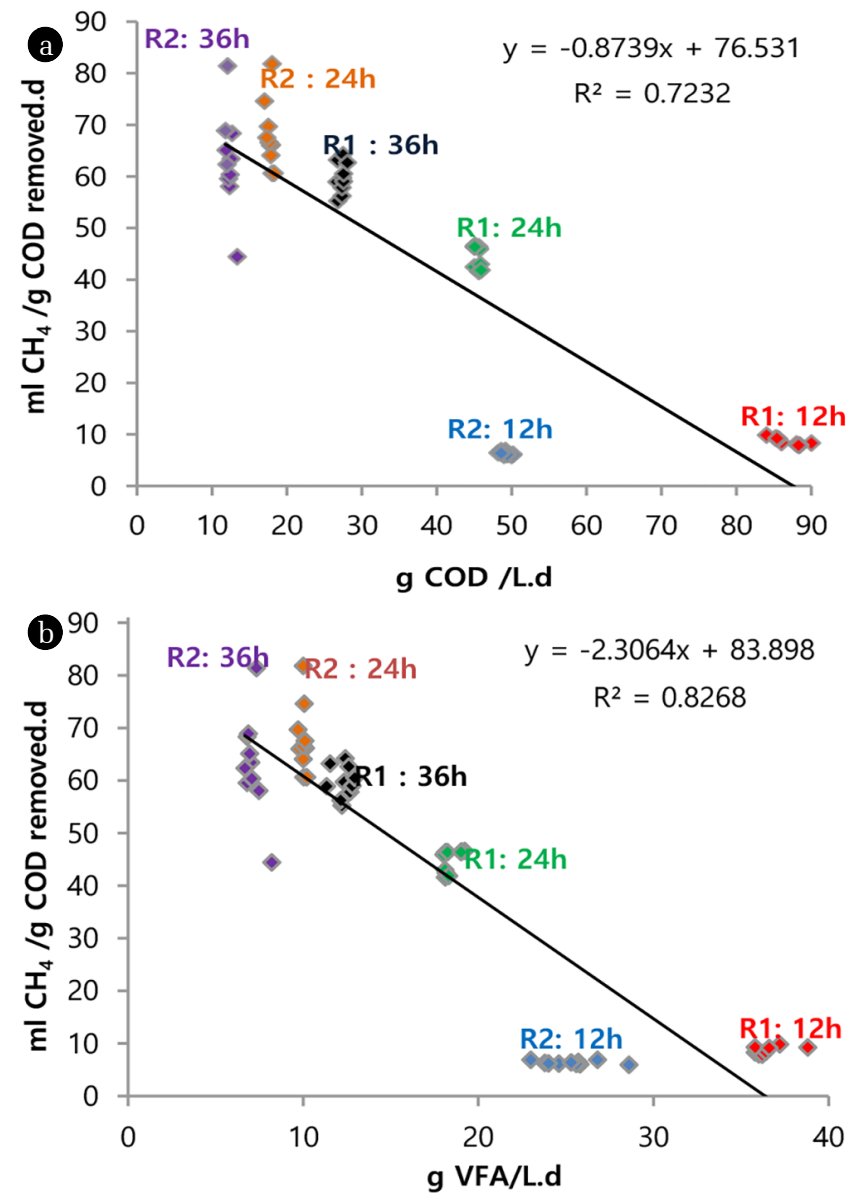

Fig. 5. UASB reactors performance in term of methane to removed COD ratio as a function of COD (a) and VFA (b) feeding rate for the three applied HRT (36 h, $24 \mathrm{~h}$ and $12 \mathrm{~h}$ ).

$12 \mathrm{~h}$, reduced considerably the performance of the process. It was clear that shortening HRT makes the digestion process close to the critical overloading range and resulted in poor performance. On the opposite, decreasing organic feeding rate, associated with HRT increase, had a strong linear positive correlation with the performance of the digestion. At the same time, reactors comparison revealed that COD and VFA loss at the first reactor, due to biological consumption, correlated positively with methane recovery performance increase from the first to the second reactors. Within favorable feeding rate range, the calculated correlation coefficient between Reactor 1 and 2 were highly significant and were in the range of 0.91-0.99 and 0.90-0.98 for COD and VFA respectively (Fig. 5). Therefore, both HRT and UASB stage results agree with the fact that organic feeding rate was the main parameters determining the anaerobic digestion performance. These results agree with most UASB anaerobic digestion studies for which COD is major and key parameters which become usually limiting factors at values closes to 32 g/L.d [57, 65]. Similarly, the VFA critical threshold was reported to vary within a large range depending on digestion conditions and waste characteristics[66-68]. For landfill leachates and food leachates, optimal $\mathrm{AD}$ performances were usually recorded at low values. Commonly, $\mathrm{AD}$ became severely stressed with VFA rising to $20 \mathrm{~g} / \mathrm{L}$ [69] and this is in good agreement with our results. It should be highlighted at the same time that qualitative VFA change may also occur with more methane precursor synthesis during the first UASB step, resulting in higher performance at the second step. Additional UASB stage is consequently a valuable option since it may surely improve both biogas yield and COD removal rate. Identification of optimal UASB stage is however still needed and represents a promising research perspective.

\section{Conclusions}

Fresh leachates are a potential source of additional biogas recovery in landfills. These effluents are however highly acid and present high COD load who makes them not suitable to anaerobic digestion. The present study concludes to the fact that acidity correction and short aeration pretreatment improve considerably start-up anaerobic digestion conditions trough significant VFA (20.3\%), COD (19.14\%) and ammonium (75.87\%) reduction, and makes anaerobic recovery of COD-rich leachates highly feasible. When the aerobic pretreatment was coupled to the UASB process, the overall treatment achieved significant abatement up to $88.66 \%$, 83.6\%, and $70.39 \%$ for $\mathrm{NH}_{4}^{+}$, COD, and VFA, respectively. Significant and stable biogas production up to 2,470 $\mathrm{mL}$ biogas/L and $123 \mathrm{~mL} \mathrm{CH}_{4} / \mathrm{g} \mathrm{COD}$ removed, was also possible at the lab scale. The success of the treatment was depending directly on inlet organic load with a critical threshold at $45.37 \mathrm{~g} \mathrm{COD/L.d} \mathrm{and} 18.43 \mathrm{~g}$ VFA/L.d. Coupling aerobic pretreatment to anaerobic multistage UASB may, therefore, be an interesting treatment that could contribute to enhancing significantly biogas production in the case of mots Moroccans landfills. At real scale, caution should, however, be taken since the COD and organic load of leachates may present significant seasonal variations and may, therefore, enhance considerably overloading risk and digestion failure. Consequently, deeply investigations to improve both the aerobic and anaerobic stage are still recommended in order to meet real conditions constraints.

\section{Acknowledgments}

This work was supported by official grant of University Sultan Moulay Slimane, Morocco. Authors are grateful to Casa Technique Company for allowing leachate collection and sampling and Cheriffien Office of Phosphate OCP for providing sludge inoculum.

\section{Author Contributions}

A.M. (Ph.D. student) conducted all the experiments works and wrote the manuscript. I.Q. (Ph.D. student) revised the manuscript. A.O. (Professor) wrote and revised the manuscript.

\section{References}

1. Peng Y. Perspectives on technology for landfill leachate treatment. Arab. J. Chem. 2017;10:S2567-S2574. 
2. Sil A, Kumar S. Landfill Leachate Treatment. In: Current Developments in Biotechnology and Bioengineering. Elsevier; 2017. p. 391-406.

3. Govahi S, Karimi-Jashni A, Derakhshan M. Treatability of landfill leachate by combined upflow anaerobic sludge blanket reactor and aerated lagoon. Int. J. Environ. Sci. Technol. 2012;9:145-151.

4. Renou S, Givaudan JG, Poulain S, Dirassouyan F, Moulin P. Landfill leachate treatment: Review and opportunity. J. Hazard. Mater. 2008;150:468-493.

5. Ai J, Wu X, Wang Y, Zhang D, Zhang H. Treatment of landfill leachate with combined biological and chemical processes: changes in the dissolved organic matter and functional groups. Environ. Technol. 2017;1-7.

6. Renou S, Givaudan JG, Poulain S, Dirassouyan F, Moulin P. Landfill leachate treatment: Review and opportunity. J. Hazard. Mater. 2008;150:468-493.

7. Guo J-S, Abbas AA, Chen Y-P, Liu Z-P, Fang F, Chen P. Treatment of landfill leachate using a combined stripping, Fenton, SBR, and coagulation process. J. Hazard. Mater. 2010;178:699-705.

8. Li H, Zhou S, Sun Y, Feng P, Li J. Advanced treatment of landfill leachate by a new combination process in a full-scale plant. J. Hazard. Mater. 2009;172:408-415.

9. Ferraz FM, Povinelli J, Vieira EM. Ammonia removal from landfill leachate by air stripping and absorption. Environ. Technol. (United Kingdom). 2013;34:2317-2326.

10. Kurniawan TA, Lo W, Chan GY. Physico-chemical treatments for removal of recalcitrant contaminants from landfill leachate. J. Hazard. Mater. 2006;129:80-100.

11. Wei Y, Ji M, Li R, Qin F. Corrigendum to organic and nitrogen removal from landfill leachate in aerobic granular sludge sequencing batch reactors. Waste Manag. 2012;32:1277-1278.

12. Zhang T, Ding L, Ren H. Pretreatment of ammonium removal from landfill leachate by chemical precipitation. J. Hazard. Mater. 2009;166:911-915.

13. Saleh TA. Characterization, determination and elimination technologies for sulfur from petroleum: Toward cleaner fuel and a safe environment. Trends Environ. Anal. Chem. 2020;25: e00080.

14. Saleh TA. Nanomaterials: Classification, properties, and environmental toxicities. Environ. Technol. Innov. 2020;20:101067.

15. Alswat AA, Ahmad MB, Saleh TA, Hussein MB, Ibrahim NA. Effect of zinc oxide amounts on the properties and antibacterial activities of zeolite/zinc oxide nanocomposite. Mater. Sci. Eng. C. 2016;68:505-511.

16. Alswat AA, Ahmad MB, Hussein MZ, Ibrahim NA, Saleh TA. Copper oxide nanoparticles-loaded zeolite and its characteristics and antibacterial activities. J. Mater. Sci. Technol. 2017;33:889-896.

17. Kotb E, Ahmed AA, Saleh TA, Ajeebi AM, Al-Gharsan MS, Aldahmash NF. Pseudobactins bounded iron nanoparticles for control of an antibiotic-resistant Pseudomonas aeruginosa ryn32. Biotechnol. Prog. 2020;36.

18. El-Gohary FA, Kamel G. Characterization and biological treatment of pre-treated landfill leachate. Ecol. Eng. 2016;94:268-274.

19. Luczkiewicz A, Jankowska K, Bray R, et al. Antimicrobial resistance of fecal indicators in disinfected wastewater. Water Sci.
Technol. 2011;64:2352-2361.

20. Zayen A, Schories G, Sayadi S. Incorporation of an anaerobic digestion step in a multistage treatment system for sanitary landfill leachate. Waste Manag. 2016;53:32-39.

21. Cheng S, Xing D, Call DF, Logan BE. Direct biological conversion of electrical current into methane by electromethanogenesis. Environ. Sci. Technol. 2009;43:3953-3958.

22. Jung S, Regan JM. Influence of external resistance on electrogenesis, methanogenesis, and anode prokaryotic communities in microbial fuel cells. Appl. Environ. Microbiol. 2011;77: 564-571.

23. Park JH, Park JH, Lee SH, Jung SP, Kim SH. Enhancing anaerobic digestion for rural wastewater treatment with granular activated carbon (GAC) supplementation. Bioresour. Technol. 2020;315:123890.

24. Fisgativa H. Study of the impact of aerobic pretreatment on anaerobic digestion of food waste [Thesis]. Rennes: Université de Rennes 1; 2016.

25. Shin J, Kim YB, Jeon JH, Choi S, Park IK, Kim YM. Biomethanation of Sewage Sludge with Food Waste Leachate Via Co-Digestion. J. Microbiol. Biotechnol. 2017;27:1513-1518.

26. Kim HW, Nam JY, Shin HS. A comparison study on the high-rate co-digestion of sewage sludge and food waste using a temperature-phased anaerobic sequencing batch reactor system. Bioresour. Technol. 2011;102:7272-7279.

27. Ma Y, Yin Y, Liu Y. New insights into co-digestion of activated sludge and food waste: Biogas versus biofertilizer. Bioresour. Technol. 2017;241:448-453.

28. Koch K, Plabst M, Schmidt A, Helmreich B, Drewes JE. Co-digestion of food waste in a municipal wastewater treatment plant: Comparison of batch tests and full-scale experiences. Waste Manag. 2016;47:28-33.

29. Koch K, Plabst M, Schmidt A, Helmreich B, Drewes JE. Co-digestion of food waste in a municipal wastewater treatment plant: Comparison of batch tests and full-scale experiences. Waste Manag. 2016;47:28-33.

30. Luo J, Qian G, Liu J, Xu ZP. Anaerobic methanogenesis of fresh leachate from municipal solid waste: A brief review on current progress. Renew. Sustain. Energy Rev. 2015;49:21-28.

31. Kalčíková G, Tratar Pirc E, Žgajnar Gotvajn A. Aerobic and anaerobic biodegradation potential of leachate from old active landfill. Desalin. Water Treat. 2016;57:8619-8625.

32. Mendez R, Lema JM, Blazquez R, Pan M, Forjan C. Characterization, digestibility and anaerobic treatment of leachates from old and young landfills. Water Sci. Technol. 1989;21: 145-155.

33. Castillo E, Vergara M, Moreno Y. Landfill leachate treatment using a rotating biological contactor and an upward-flow anaerobic sludge bed reactor. Waste Manag. 2007;27:720-726.

34. Castrillón L, Fernández-Nava Y, Ulmanu M, Anger I, Marañón E. Physico-chemical and biological treatment of MSW landfill leachate. Waste Manag. 2010;30:228-235.

35. Ye J, Mu Y, Cheng X, Sun D. Treatment of fresh leachate with high-strength organics and calcium from municipal solid waste incineration plant using UASB reactor. Bioresour. Technol. 2011;102:5498-5503.

36. Gunay A, Karadag D, Tosun I, Ozturk M. Combining anerobic degradation and chemical precipitation for the treatment of 
high strength, strong nitrogenous landfill leachate. Clean-Soil Air Water. 2008;36:887-892.

37. Bohdziewicz J, Kwarciak A. The application of hybrid system UASB reactor-RO in landfill leachate treatment. Desalination 2008;222:128-134.

38. Kennedy KJ, Lentz EM. Treatment of landfill leachate using sequencing batch and continuous flow upflow anaerobic sludge blanket (UASB) reactors. Water Res. 2000;34:3640-3656.

39. Khan AA, Mehrotra I, Kazmi AA. Sludge profiling at varied organic loadings and performance evaluation of UASB reactor treating sewage. Biosyst. Eng. 2015;131:32-40.

40. Tawfik A, Sobhey M, Badawy M. Treatment of a combined dairy and domestic wastewater in an up-flow anaerobic sludge blanket (UASB) reactor followed by activated sludge (AS system). Desalination 2008;227:167-177.

41. Rizvi H, Ahmad N, Abbas F, et al. Start-up of UASB reactors treating municipal wastewater and effect of temperature/sludge age and hydraulic retention time (HRT) on its performance. Arab. J. Chem. 2015;8:780-786.

42. Chen Y, Cheng JJ, Creamer KS. Inhibition of anaerobic digestion process: A review. Bioresour. Technol. 2008;99:4044-4064.

43. Sung S, Liu T. Ammonia inhibition on thermophilic anaerobic digestion. Chemosphere 2003;53:43-52.

44. Wens P, Vercauteren T, De Windt W, Verstraete W. Factors inhibiting anaerobic degradation in a landfill. In: 8th International Waste Management and Landfill Symposium (Sardinia 2001). CISA Publishers; 2001. p. 13-20.

45. Moujannı A, Qarraey I, Ouatmane A. Anaerobic codigestion of urban solid waste fresh leachate and domestic wastewaters: Biogas production potential and kinetic. Environ. Eng. Res. 2018;24:38-44.

46. Carlsson M, Lagerkvist A, Morgan-sagastume F. The effects of substrate pre-treatment on anaerobic digestion systems : A review. Waste Manag. 2012;32:1634-1650.

47. Smaoui Y, Bouzid J, Sayadi S. Combination of air stripping and biological processes for landfill leachate treatment. Environ. Eng. Res. 2019;25:80-87.

48. Smaoui Y, Mlaik N, Bouzid J, Sayadi S. Improvement of anaerobic digestion of landfill leachate by using coagulation-flocculation, Fenton's oxidation and air stripping pretreatments. Environ. Prog. Sustain. Energy. 2018;37:1041-1049.

49. Ferraz FM, Povinelli J, Vieira EM. Ammonia removal from landfill leachate by air stripping and absorption. Environ. Technol. 2013;34:2317-2326.

50. Nielfa, A., Cano, R., Fdz-Polanco M. Theoretical methane production generated by the co-digestion of organic fraction municipal solid waste and biological sludge. sludge. Biotechnol. 2015;5:14-21.

51. Iqbal Syaichurrozi B, Sumardiono S. Kinetic Model of Biogas Yield Production from Vinasse at Various Initial pH: Comparison between Modified Gompertz Model and First Order Kinetic Model. Res. J. Appl. Sci. Eng. Technol. 2014;7:2798-2805.

52. Lo HM, Kurniawan TA, Sillanpää MET, et al. Modeling biogas production from organic fraction of MSW co-digested with MSWI ashes in anaerobic bioreactors. Bioresour. Technol. 2010;101:6329-6335.

53. Rodier J, Bazin C, Broutin JP. L'analyse de l'eau: eaux naturelles, eaux résiduaires et de mer: chimie, physico-chimie, microbiologie, biologie, interprétation des résultats. Dunod; 1996.

54. Zickefoose C, Hayes R. Anaerobic Sludge Digestion: Operations Manual. Washington D.C.: united States Environmental Protection Agency; 1976.

55. Chofqi A, Younsi A, Lhadi EK, Mania J, Mudry J, Veron A. Lixiviat de la décharge publique d'El Jadida (Maroc) : caractérisation et étude d'impact sur la nappe phréatique. Déchets, Sci. Technol. 2007;46:4-10.

56. Pan Z, Zhou J, Lin Z, et al. Effects of COD/TN ratio on nitrogen removal efficiency, microbial community for high saline wastewater treatment based on heterotrophic nitrification-aerobic denitrification process. Bioresour. Technol. 2020;301:122726.

57. Luo J, Qian G, Liu J, Xu ZP. Anaerobic methanogenesis of fresh leachate from municipal solid waste: A brief review on current progress. Renew. Sustain. Energy Rev. 2015;49:21-28.

58. Liu J, Luo J, Zhou J, Liu Q, Qian G, Xu ZP. Inhibitory effect of high-strength ammonia nitrogen on bio-treatment of landfill leachate using EGSB reactor under mesophilic and atmospheric conditions. Bioresour. Technol. 2012;113:239-243.

59. Ko JH, Ma Z, Jin X, Xu Q. Effects of Aeration Frequency on Leachate Quality and Waste in Simulated Hybrid Bioreactor Landfills Effects of aeration frequency on leachate quality and waste in simulated hybrid bioreactor landfills. J. Air Waste Manage. Assoc. 2016;66:1245-1256.

60. Lei X, Sugiura N, Feng C, Maekawa T. Pretreatment of anaerobic digestion effluent with ammonia stripping and biogas purification. J. Hazard. Mater. 2007;145:391-397.

61. Lei X, Sugiura N, Feng C, Maekawa T. Pretreatment of anaerobic digestion effluent with ammonia stripping and biogas purification. J. Hazard. Mater. 2007;145:391-397.

62. Wu C, Yu M, Huang Q, et al. Stimulation of methane yield rate from food waste by aerobic pre-treatment. Bioresour. Technol. 2018;261:279-287.

63. Wang Z, Banks CJ. Report: Anaerobic digestion of a sulphate-rich high-strength landfill leachate: The effect of differential dosing with FeCl3. Waste Manag. Res. 2006;24:289-293.

64. Shiskoswski DM MD. Biological treatment of a high ammonia leachate: influence of external carbon during initial startup. Water Res. 1998;32:2533-2541.

65. Pérez M, Romero LI, Sales D. Comparative performance of high rate anaerobic thermophilic technologies treating industrial wastewater. Water Res. 1998;32:559-564.

66. Li Y-Y, P. Fang HH, Chen T, Chui H-K. UASB Treatment of Wastewater Containing Concentrated Benzoate. J. Environ. Eng. 1995;121:748-751.

67. Han S, Kim S, Shin H. UASB treatment of wastewater with VFA and alcohol generated during hydrogen fermentation of food waste. Process Biochem. 2005;40:2897-2905.

68. Begum S, Anupoju GR, Sridhar S, Bhargava SK, Jegatheesan V, Eshtiaghi N. Evaluation of single and two stage anaerobic digestion of landfill leachate: Effect of $\mathrm{pH}$ and initial organic loading rate on volatile fatty acid (VFA) and biogas production. Bioresour. Technol. 2018;251:364-373.

69. Zhang Y, Banks CJ, Heaven S. Anaerobic digestion of two biodegradable municipal waste streams. J. Environ. Manage. 2012;104:166-174. 